\title{
Perceptions and Trends of Booking Online Payments in Tourism
}

\author{
Fernando Almeida \\ Faculty of Engineering of Oporto University, INESC TEC, Porto, Portugal \\ João Almeida \\ Higher Polytechnic Institute of Gaya, ISPGaya, V.N.Gaia, Portugal \\ Miguel Mota \\ Higher Polytechnic Institute of Gaya, ISPGaya, V.N.Gaia, Portugal
}

Received: 21 April 2018. Revision received: 11 April 2019. Accepted: 9 May 2019

\begin{abstract}
Online booking services for accommodation have gained increasing importance in the tourist services provided by tour operators. However, one of the major difficulties associated with this process is the choice of payment method that may be appropriate to the needs and desires of tourists. In this sense, this study intends to identify the main dimensions that characterize each of the payment methods and, for each of them, seeks to characterize the tourists' perception of the main advantages and limitations associated with them. This study adopts a quantitative analysis methodology through the use of an online survey. A final sample of 238 responses was considered. The data were explored using Stata software and adopting statistical inference methods based on the analysis of variance. The findings allow us to conclude that cash payment is the payment method that simultaneously presents better availability and easiness. However, it is also the most insecure of the considered payment methods. For its part, the debit card is considered the safest method. This study didn't intend to analyze the evolution of these payment methods over time. Furthermore, other emerging payment methods such as NFC, QR codes, mobile wallets have gained recent relevance and may be interesting their inclusion in future studies. The results are mainly relevant for tourism agencies and demonstrate that tourists' perception is conditioned mainly by their age and the number of performed trips.
\end{abstract}

Key words: Online reservation, tourism services, payment methods, security, choice behavior

JEL Classification: Z30, Z32

\section{Introduction}

Nowadays, the importance of the online booking process is high due to the evolution of related technologies and applications. Increasingly, tourism consumers use the internet as a mean to plan their travels and make their accommodation reservations. Information technologies enable to attract new tourists and facilitate the booking process, which is available 24 hours daily from anywhere.

The hotel industry assumes a relevant role in the development of a tourist region and in the competitiveness of tourism, being its effect particularly visible in most competitive tourism destinations (Attila, 2016). The online booking process is also essential for hotels because it allows 
them to easily know how many rooms are reserved for a certain date and how much they charged at the end of a certain period and through the website they can get the opinion and feedback of customers about their accommodation. Through it, hotels have also more publicity and people become aware of its existence. According to Filieri \& McLeay (2013), online reviews have a significant influence on the buying behavior of tourists.

Online travel sales show significant growth rates. In 2016, global online travel sales represented 565 billion US dollars, and it is projected to grow to 756 billion US dollars in 2019 (Statista, 2017). The hotel booking process has experienced significant changes in recent years. The Internet plays a key role in the booking process and hotels increasingly need to have integrated systems with travel e-commerce companies. Deshmukh (2017) states that the main trends in the evolution of tourism in the coming years include the analysis of a large volume of data, reformulation of the business model, payments and data security, and mobile data integration.

One of the conditions inherent to the success of the online booking process is the existence of a payment method that is suitable to the needs and desires of the users. In this sense, this study seeks to assess the users' precepts about the payment methods most used currently in the online booking process considering several dimensions (e.g., availability, easiness, and security) and also various demographic, social and financial characteristics (e.g., gender, age, number of trips performed by year, and amount spent in accommodations). The paper is organized as follows: we initially perform a literature review on payments methods adopted in e-commerce and touristic services. Next, we present the adopted methodology and the five research questions established for this study. After that, we present and discuss the main results. Finally, the main conclusions are drawn.

\section{Literature Review}

\subsection{Payments in e-commerce}

Most of the research done on online payment methods focus on e-commerce. In this sense, a literature review was carried out in this area, since e-commerce payment methods are common to those used in tourism.

The payment process has become more complex and dynamic. Innovation in the provision of a larger diversified set of payments is important for both consumers and operators, but this raises potential issues in data protection and security (Anderson, 2012). Teoh et al. (2013) used a multiple linear regression model to reveal that factors such as self-efficacy and ease to use influence the consumers' perception toward the benefits offered by e-payments. Bogdan-Alexandru (2015) advocates that e-payments systems should offer reliable and secure methods to authenticate their customers. He also states that the level of authentication used should be associated with the risks inherent to them. Therefore, in a first instance, the level of risk associated with each payment method should be analyzed. Solat (2017) explored the vulnerabilities of electronic payment systems. The study presented a comprehensive survey where several scenarios are used to demonstrate that electronic payments methods can be corrupted. The findings allow us to conclude that all kinds of electronic payments systems (e.g., card-present, card-not-present, contactless, decentralized) have security breaches in security, user privacy, performance, and anonymity.

Jiemiao (2011) identifies five security requirements for an online payment system: (i) information confidentiality; (ii) data integrity; (iii) authentication of participants; (iv) nonrepudiation; and (v) end-user implementation requirements (e.g., usability, flexibility, reliability, 
availability, interoperability, etc.). Niranjanamurthy \& Chahar (2013) consider that e-commerce security contains six security dimensions: (i) integrity; (ii) non-repudiation; (iii) authentication; (iv) confidentiality; (v) privacy; and (vi) availability. Hal (2014) proposes several dimensions of analyzing retail payment systems, respectively: (i) finality and reversibility; (ii) universality; (iii) recordkeeping; (iv) liquidity; (v) security and safety; (vi) financial inclusion and access; and (vii) fungibility and ease of use. Hal (2014) considers that debit and credit cards are the most desirable payment system for achieving the benefits of the seven above identified dimensions, which is being confirmed by the increasing number of operators that have adopted card payments. Goczek \& Witkowski (2015) used econometric models to analyze the determinants of the development of the card payment system. The study used survey data in Poland to conclude that demographic, social and economic variables have a significant influence on the number of card payment transactions.

One of the most complete and up to date report on payment methods in e-commerce was developed by Lupu, Mual, \& Stiphout (2016). In this report, they analyzed innovation drives in ecommerce payments and contextualize the online payment methods adopted in e-commerce solutions. Four trends driving innovation were found: (i) consumer behavior and expectations is more demanding; (ii) emergence of social platforms of e-commerce; (iii) technology-driven innovation with the growth of mobile apps, cloud technology, artificial intelligence and internet of things; and (iv) regulatory reforms and frameworks in e-commerce and online payment ecosystem. Six payment instruments were identified by Lupu, Mual \& Stiphout (2016): (i) card payments; (ii) bank transfer payments; (iii) direct debit payments; (iv) cash payments; (v) crypto-currency payments; and (vi) direct carrier payments. These payments instruments can be used in different contexts, such as pay in advance, payment on delivery, or after delivery payment.

Another study of great importance for its comprehensiveness was developed by KPMG in 2017 , in which it becomes possible to analyze the adoption of e-commerce according to multiple perspectives, such as the profile of consumers, products and services most acquired, purchasing channels, payment methods, etc. Payment methods emerge as the world's fourth most important attribute in consumer choice, and in some European countries, in India and Latin America, this attribute is even more important than their options for delivery or returns. KPMG (2017) also describes the distribution of payment methods for each region. It is possible to reach the following conclusions: (i) the six most widely used methods of payment are: credit card, PayPal, debit card, bank transfer, cash on delivery (COD), and gift card; (ii) the distribution percentage of each payment method is relatively heterogeneous for each region, with a smaller percentage of payments per bank credit card in Europe; COD is an important payment alternative in Eastern Europe \& Russia, and the use of gift cards is mainly adopted in North America.

In addition, we also analyzed in the literature the performance of several payment methods in traditional commerce. Polasik et al. (2010) compared different point-of-sales payments under the criterion of time efficiency. Cash payments proved to be the fastest method followed by RFID stickers and mobile payments. On the other side, traditional standard cards have shown lower performance and, sometimes, this payment type is not available in all point-of-sales. Schuh \& Stavins (2011) used data from a US representative survey to conclude that four payments methods emerge as important in determining consumer payment adoption and behavior, respectively: (i) setup complexity; (ii) record keeping; (iii) security; and (iv) cost. This study also indicates that the increase of costs of debit cards may lead to a reduction of this payment type.

Finally, it is meaningful to highlight the emerging role of the sharing economy and its impact on e-commerce. Conceptually the sharing economy is a sustainable economic ecosystem built around the sharing of services, products and human resources (Franken \& Schor, 2017). It 
includes creating, producing, distributing, sharing and consuming goods and services by people and businesses, focused on people. Sharing economy has influenced the tourism sector particularly the housing and hotel markets (Ključnikov et al., 2018). The methods of payment in sharing economy become more complex, because the received money needs to be divided correctly among the various actors, using several currencies and dates (Snoek, 2016). Another factor to be taken into consideration is that the available payment methods should consider the regional knowledge, because one type of method popular in one country may not be in another (Snoek, 2016).

\subsection{Payments in tourism}

The study of payment methods in tourism and the determinants in their choice have been little explored. Most of the existing information on the subject is based on technical reports from international consulting firms and regulators. At this level, we highlight the report offered by the World Travel \& Tourism Council that looks at the global economic impact and issues of travel and tourism. Historically, three types of payments stand out in tourism: (i) payments with cash; (ii) traveler's check; and (iii) payments with cards. Also, in recent years, significant technological evolution has been introduced in the sector, mainly due to the massive use of smartphones. This has led to the emergence of innovative technologies and services, such as Fintech (WTTC, 2017).

There have also been news articles about paradigm shifts in payments' methods. Peng, Xiong, \& Yang (2012) used the technology acceptance model (TAM) to demonstrate that perceived security and compatibility are key determinants in the acceptance of tourism mobile payments. Additionally, the increasing access to booking websites using mobile devices has led to changes in payment methods, with the emergence of so-called Alternative Payment Methods (APMs). In the APMs stand out in some markets the PayPal and the mobile app WeChat in China (Oliosi, 2017). Contactless cards have also increased consumer popularity, which means that traditional debit cards can conquer new markets in the tourism industry (Burke-Kennedy, 2017). The emergence of Airbnb, which is an online booking platform, also encouraged the emergence of new payment methods (Zervas et al., 2017). Payment options may include credit cards, paypal, alipay, postepay, hypercard, payU, Google Wallet or Apple Pay (Airbnb, 2018). Some of these methods of payment only work in some markets, such as alipay in China, payU in India, or the postepay in Italy. Other emergent payment methods have also appeared which use a payment app to pay directly bills and perform transactions between friends. These payment apps (e.g., Venmo, Apple Pay, WeChat Pay, etc.) have become popular among younger generations (Finley, 2018).

There are limited scientific studies in this area in the literature. Two exceptions can be found, but they look to different perspectives of the payment' types in tourism. Gul (2014) looks at the effect of using credit cards on domestic and international Turkish tourism demand. He advocates that the increasing use of credit cards, the rising of individual income and other industrial developments play a decisive role in the growth of the tourism sector. Berezina (2010) analyzes the main barriers and key issues that hotel industry professionals face during the implementation of the Payment Card Industry Data Security Standards (PCI DSS). These standards are essential to protect their payment systems from breaches and theft of cardholder data and, consequently, to offer to customers a secure payment solution (PCI, 2017). The main issues identified by Berezina (2010) for the implementation of PCI DSS include: (i) high costs of implementation and maintenance; (ii) lack of qualified staff; (iii) inadequate staff training; (iv) high complexity of the standard; and (v) lack of vendors' support. 


\section{Methodology}

This study aims to perceive how online payment methods are used in the process of booking touristic accommodations. Five research questions (RQs) were defined:

- RQ1 - What is the perception of tourists on the main benefits and disadvantages associated with each method of payment?

- RQ2 - Do the benefits and disadvantages of each method of payment is perceived differently considering the tourists' gender?

- RQ3 - Do the benefits and disadvantages of each method of payment is perceived differently by tourists with different age groups?

- RQ4 - Do the benefits and disadvantages of each method of payment is perceived differently by tourists with higher number of trips per year?

- RQ5 - Do the benefits and disadvantages of each method of payment is perceived differently by tourists with greater value spent on their accommodations?

The study adopts a quantitative approach based on a survey created using the Google Drive platform. The survey was delivered to institutional partners of our university and it was available in two professional LinkedIN groups in the tourism field (i.e., Tourism 2.0 and Online Travel and Tourism). The questionnaire was available during two months (from 15th January 2018 to 15th March 2018).

Surveys offer several important benefits. Mathiyazhagan \& Nandan (2010) state that surveys represent a relatively inexpensive data collection method and it can access to a wide range of participants. Queirós et al. (2017) refer that when surveys have a significant response rate, then this reduces the possibility of evaluator bias. However, it is imperative to mitigate the potential issues of online surveys (Evans \& Mathur, 2005). At this level, Nulty (2008) presents three suggestions to improve the effectiveness of online surveys, respectively: (i) obtain a high response rate; (ii) take into account possible issues when designing the survey; and (iii) use data derived from multiples methods of gathering feedback. Lefever, Dal, \& Matthíasdóttir (2007) emphasize that it is important to understand the motivation and reasons for the results obtained, since the isolated interpretation of survey data, without their proper contextualization, can lead to skewed conclusions.

Table 1 Structure of the questionnaire

\begin{tabular}{|l|l|}
\hline \multicolumn{1}{|c|}{ Section } & \multicolumn{1}{c|}{ Description } \\
\hline \hline Control data & $\begin{array}{l}\text { Information regarding the gender, age, number of trips, characteristics } \\
\text { of those trips and amount spent. }\end{array}$ \\
\hline Availability dimension & $\begin{array}{l}\text { Evaluation of the perception of each payment method according to the } \\
\text { "availability" dimension. Availability is defined as "the state of being } \\
\text { able to be obtained or used" (MacMillan Dictionary, 2018). }\end{array}$ \\
\hline Easiness dimension & $\begin{array}{l}\text { The perception of "easiness" dimension is also assessed. Easiness is } \\
\text { defined as "not difficult to know, understand, or believe" (MacMillan } \\
\text { Dictionary, 2018). }\end{array}$ \\
\hline Security dimension & $\begin{array}{l}\text { A similar approach was also performed for the "security" dimension. } \\
\text { Security is defined as "safety from attack, harm, or damage" } \\
\text { (MacMillan Dictionary, 2018). }\end{array}$ \\
\hline
\end{tabular}

Source: Authors

The questionnaire is composed of 26 questions divided into four sections (i.e., control data, availability dimension, easiness dimension, and security dimension). The "control data" section, 
together with the last three sections, allows us to respond to RQ2, RQ3, RQ4, and RQ5. To answer RQ1 we only need the last three sections of the questionnaire. The purpose of each section is detailed in Table 1.

Three classes of payments (i.e., payments with cash, traveler's check and payments with cards) were considered due to its high relevance in the tourism field. Within the card payment segment, we distinguish between credit and debit card payments. Additionally, three additional payment methods were also considered due to their wide adoption in the e-commerce field (i.e., bank transfer, paypal, and gift cards).

\section{Analysis and Discussion of Results}

A total of 251 answers were collected and analyzed. Thirteen invalid responses have been removed from 251 due to having some missing answers and the same responses to all the questions. The final accepted sample is 238 , which is appropriate for this study. The collected data have the following distribution:

- Sex - 129 men and 109 women. We have approximately $54.2 \%$ of respondents from males sex;

- Age - 61 (18-29 years old); 88 (30-49 years old); 42 (50-64 years old) and 47 (65 years and over). Most of our respondents (62.61\%) are under 50 years old;

- Number of trips per year - 95 (1-2 trips); 86 (3-5 trips) and 57 (more than 5 trips). The majority of our respondents don't realize more than 2 trips per year;

- Characteristics of the trips - 116 (personal); 35 (professional) and 87 (equal). Only $14.71 \%$ of our respondents realize only professional trips;

- Average of the amount spent in their accommodations - 34 (less than 50€); 96 (50€$100 €) ; 96$ (100€-250€) and 12 (more than 250€). Approximately $80.67 \%$ of our respondents spend between $50 €-250 €$ per trip.

\subsection{RQ1 - What is the perception of tourists on the main benefits and disadvantages associated with each method of payment?}

In a first phase, we analyze the perception of the respondents about the advantages and limitations associated with each payment method considering "availability", "easiness" and "security" dimensions. Table 2 presents a ranking of payment's types per dimension and Figure 1 helps us to analyze and interpret the evaluation of each payment method according to the three dimensions. The results demonstrate that:

- Availability dimension - cash payments and debit card have the highest average. On the other side, the methods of payment with less availability are: (i) traveler's check; (ii) paypal; and (iii) gift cards. In fact, traveler's checks have been replaced by the widespread acceptance of credit cards and debit cards. Shafer (2017) stated that another factor that contributed to decline in their use is the fees charged by the issuer and agent, especially when compared to the majority of credit cards. Analyzing the standard deviation we found that paypal is the payment method that registers the greatest dispersion of responses. This situation may be related to a less aware of this mean of payment by respondents and, therefore, they assume their unavailability; 
- Easiness dimension - cash payment and debit card stand out as the easiest payment methods to use. On the other side, the most difficult payment methods are the traveler's check and gift cards. Connolly (2014) emphasizes the difficulties in the use of gift cards, especially in services of greater complexity and in which it becomes necessary a greater personalization of the service to the expectations of the client. Looking to the standard deviation two types of payments may be highlighted: (i) cash payment has a very low standard deviation with almost all of respondents stating that it is very easy to use; and (ii) paypal has a greater dispersion in responses;

- Security dimension - debit card and bank transfer are considered the safest payment methods. Despite this, it is important to recognize that persist some security challenges and vulnerabilities which are reported in several studies (Kovács \& David, 2016; Korauš et al., 2017). At this level, deserves special mention the cloning of cards, extortions to get personal access codes and theft of data in online transactions. On the other hand, the cash payment was considered the most insecure. In fact, cash payment registered just like paypal a large dispersion of responses which makes predicting a different behavior on the part of different profiles of tourists.

Table 2 Ranking of payment's types per dimension

\begin{tabular}{|l|r|r|r|}
\hline \hline \multicolumn{1}{|c|}{ Type of payment } & \multicolumn{3}{c|}{ Ranking of dimensions } \\
\hline \hline & Availability & Easiness & \multicolumn{1}{c|}{ Security } \\
\hline Cash payment & 1st & 1st & 7th \\
\hline Credit card & 3rd & 3rd & 4th \\
\hline Debit card & 2nd & 2nd & 1st \\
\hline Bank transfer & 4th & 4th & 2nd \\
\hline PayPal & 6th & 5th & 6th \\
\hline Traveler's check & 7th & 7th & 5th \\
\hline Gift cards & 5th & 6th & 3rd \\
\hline
\end{tabular}

Source: Authors

Figure 1 Evaluation of payment methods according to three dimensions

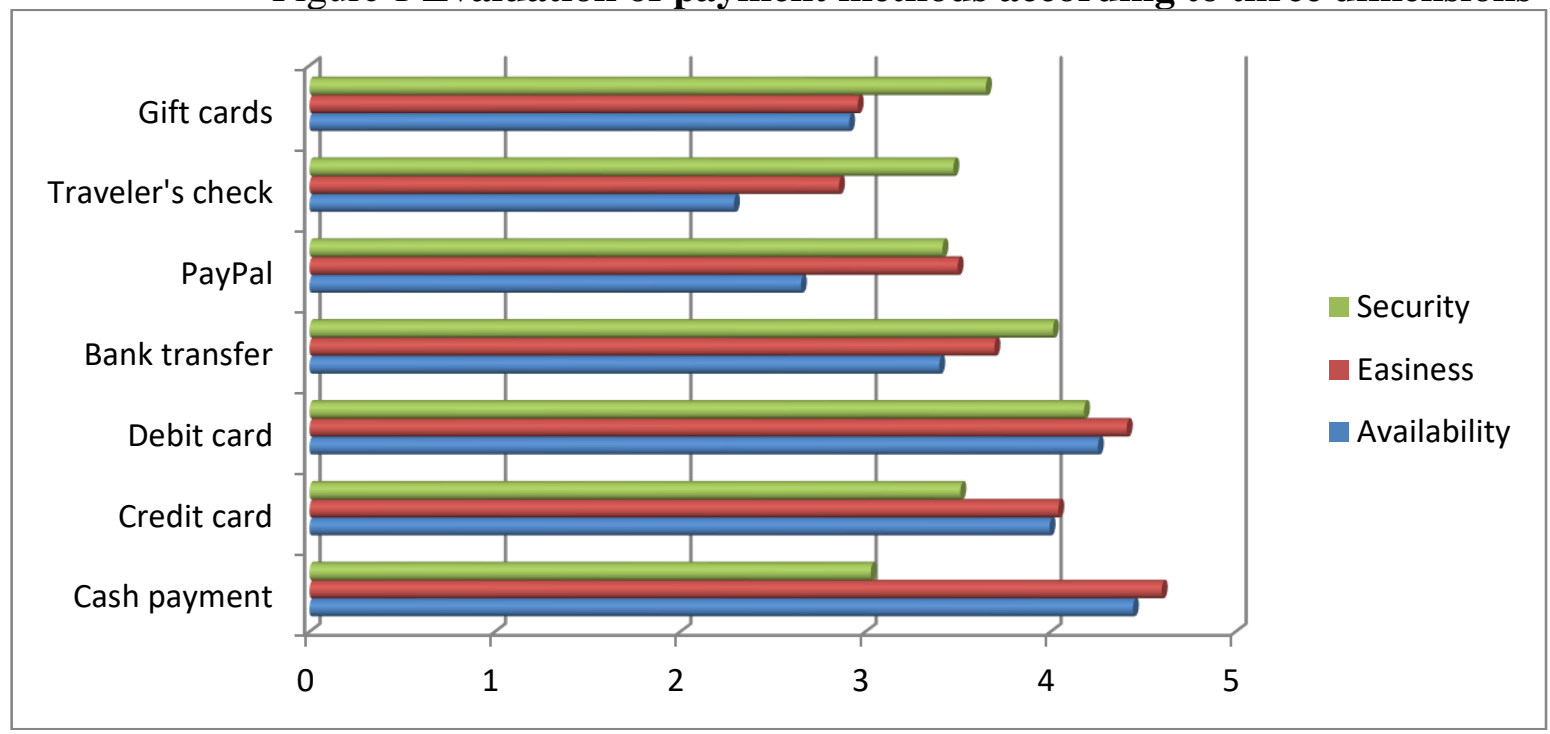

Source: Authors 


\subsection{RQ2 - Do the benefits and disadvantages of each method of payment is perceived differently considering the tourists' gender?}

We perform a two-tailed t-test in order to find evidence of a significant difference between the answers given by respondents from masculine and feminine gender. Although most statistical studies adopt an alpha level of 0.05 , it was found that the existence of a reduced number of responses in some payment categories could lead to the detection of false positives (called a Type I error). Consequently, and to increase the reliability of the results, a significance level of $1 \%$ was adopted $(\alpha=0.01)$. The statistical tests were performed using Stata v.15 software. Looking at Table 3 it is possible to conclude that only easiness and security dimensions present statistical significance differences. Female gender individuals consider that payments with credit card and debit card offer less easiness. On the same direction, female gender individuals also consider that payments with credit card, paypal and traveler's check offer less security. However, considering the total number of tested variables in this study, we can realize that tourists' gender has a residual impact on the choice of payment methods.

Table 3 Hypothesis test for tourists' gender

\begin{tabular}{|l|r|r|r|}
\hline Type of payment & $\begin{array}{c}\text { Mean (gender } \\
\text { ' 'male') }\end{array}$ & $\begin{array}{c}\text { Mean (gender } \\
\text { ' 'female') }\end{array}$ & Sig. \\
\hline \multicolumn{4}{|c|}{ Availability dimension } \\
\hline Cash payment & 4.442 & 4.450 & 0.9369 \\
\hline Credit card & 4.116 & 3.853 & 0.0211 \\
\hline Debit card & 4.310 & 4.193 & 0.2003 \\
\hline Bank transfer & 3.372 & 3.431 & 0.5543 \\
\hline PayPal & 2.729 & 2.560 & 0.2084 \\
\hline Traveler's check & 2.357 & 2.211 & 0.2157 \\
\hline Gift cards & 2.984 & 2.826 & 0.1966 \\
\hline \multicolumn{4}{|c|}{ Easiness dimension } \\
\hline Cash payment & 4.550 & 4.661 & 0.2042 \\
\hline Credit card & 4.194 & 3.862 & 0.0050 \\
\hline Debit card & 4.566 & 4.229 & 0.0001 \\
\hline Bank transfer & 3.736 & 3.651 & 0.3896 \\
\hline PayPal & 3.659 & 3.306 & 0.0191 \\
\hline Traveler's check & 2.946 & 2.752 & 0.0908 \\
\hline Gift cards & 2.984 & 2.927 & 0.6142 \\
\hline \multicolumn{4}{|r|}{ Security dimension } \\
\hline Cash payment & 2.938 & 3.138 & 0.1905 \\
\hline Credit card & 3.690 & 3.303 & 0.0014 \\
\hline Debit card & 4.256 & 4.092 & 0.0631 \\
\hline Bank transfer & 4.070 & 3.945 & 0.1870 \\
\hline PayPal & 3.643 & 3.147 & 0.0009 \\
\hline Traveler's check & 3.628 & 3.294 & 0.0021 \\
\hline Gift cards & 3.775 & 3.505 & 0.0199 \\
\hline
\end{tabular}

Source: Authors

\subsection{RQ3 - Do the benefits and disadvantages of each method of payment is perceived differently by tourists with different age groups?}

The ANOVA statistical method was employed to verify if there is a difference between the distributions of a measure among three or more groups, considering the different age groups. Table 4 allows us to conclude that there are distinct perceptions of the three dimensions considering the 
tourist's age. Individuals with more than 65 years old consider that payments with credit cards, paypal, traveler's check, and gift cards offer simultaneously less availability, easiness and security. Younger individuals express an inverse perception of this situation, and they consider that payments with paypal and gift cards are more secure. This trend also occurs in e-commerce payments, in which millennials prefer using paypal on their smartphones for paying and receiving money (Bizrate, 2016). Furthermore, debit cards are considered to have worse easiness and security among individuals over 65 years old. However, the perception regarding the availability dimension is uniform for all individuals. Finally, it is possible to conclude that the perception regarding the availability, easiness, and security of bank transfer payments is similar for all individuals.

Table 4 Hypothesis test for tourists' age

\begin{tabular}{|c|c|c|c|c|c|}
\hline Type of payment & $\begin{array}{c}\text { Mean (age }= \\
18 \text { to } 29\end{array}$ & $\begin{array}{c}\text { Mean (age }= \\
30 \text { to 49) }\end{array}$ & $\begin{array}{l}\text { Mean (age } \\
=50 \text { to 64) }\end{array}$ & $\begin{array}{c}\text { Mean (age } \\
=65 \text { and } \\
\text { over) }\end{array}$ & Sig. \\
\hline \multicolumn{6}{|c|}{ Availability dimension } \\
\hline Cash payment & 4.393 & 4.307 & 4.310 & 4.894 & $<1 \mathrm{e}^{-7}$ \\
\hline Credit card & 4.049 & 4.080 & 4.238 & 3.553 & 0.0009 \\
\hline Debit card & 4.377 & 4.227 & 4.286 & 4.128 & 0.3107 \\
\hline Bank transfer & 3.377 & 3.364 & 3.357 & 3.532 & 0.6224 \\
\hline PayPal & 3.230 & 2.909 & 2.500 & 1.553 & $<1 \mathrm{e}^{-7}$ \\
\hline Traveler's check & 2.033 & 2.670 & 2.643 & 1.596 & $<1 \mathrm{e}^{-7}$ \\
\hline Gift cards & 3.246 & 3.091 & 3.000 & 2.064 & $<1 \mathrm{e}^{-7}$ \\
\hline \multicolumn{6}{|c|}{ Easiness dimension } \\
\hline Cash payment & 4.607 & 4.511 & 4.524 & 4.830 & 0.0513 \\
\hline Credit card & 4.230 & 4.239 & 4.429 & 3.085 & $<1 \mathrm{e}^{-7}$ \\
\hline Debit card & 4.574 & 4.477 & 4.571 & 3.936 & $<1 \mathrm{e}^{-7}$ \\
\hline Bank transfer & 3.590 & 3.773 & 3.762 & 3.638 & 0.4461 \\
\hline PayPal & 4.150 & 3.989 & 3.333 & 1.894 & $<1 \mathrm{e}^{-7}$ \\
\hline Traveler's check & 2.885 & 3.023 & 3.119 & 2.277 & $<1 \mathrm{e}^{-7}$ \\
\hline Gift cards & 3.377 & 3.148 & 2.905 & 2.106 & $<1 \mathrm{e}^{-7}$ \\
\hline \multicolumn{6}{|c|}{ Security dimension } \\
\hline Cash payment & 2.705 & 2.830 & 2.690 & 4.128 & $<1 \mathrm{e}^{-7}$ \\
\hline Credit card & 3.623 & 3.773 & 3.786 & 2.638 & $<1 \mathrm{e}^{-7}$ \\
\hline Debit card & 4.311 & 4.284 & 4.333 & 3.681 & $<1 \mathrm{e}^{-7}$ \\
\hline Bank transfer & 3.984 & 4.034 & 4.095 & 3.936 & 0.7460 \\
\hline PayPal & 4.016 & 3.693 & 3.452 & 2.085 & $<1 \mathrm{e}^{-7}$ \\
\hline Traveler's check & 3.361 & 3.693 & 3.833 & 2.894 & $<1 \mathrm{e}^{-7}$ \\
\hline Gift cards & 3.885 & 3.909 & 3.786 & 2.745 & $<1 e^{-7}$ \\
\hline
\end{tabular}

Source: Authors

\subsection{RQ4 - Do the benefits and disadvantages of each method of payment is perceived differently by tourists with higher number of trips per year?}

Table 5 presents the hypothesis test carried out to study whether the number of trips (nt) per year influences the perception of availability, easiness, and security of the payment methods. Like in the previous scenario, the ANOVA method was applied. The results of this process allow us to conclude that there is significant evidence to conclude the existence of a distinct pattern of using payment methods for individuals with few trips per year (nt equal to 1 or 2) and for individuals with many trips made (nt more than 5). Thus, credit cards, paypal, traveler's check, and gift cards 
are perceived by less traveled tourists as offering lower availability, easiness and security. On the opposite side, there is an inverse perception regarding individuals who carry out a greater number of trips.

The obtained results are also relevant to conclude that individuals with fewer trips (nt equal to 1 or 2) consider that cash payment offers better security conditions when compared against individuals who perform more trip. On the contrary side, this last group of individuals considers that payments with debit and credit cards are more secure. Finally, the perception about the availability, easiness, and security of bank transfer payments is uniform for all groups of individuals, regardless of the number of trips performed by them.

Table 5 Hypothesis test for number of trips

\begin{tabular}{|l|r|r|r|r|}
\hline Type of payment & $\begin{array}{c}\text { Mean (nt = 1 } \\
\text { to 2) }\end{array}$ & $\begin{array}{c}\text { Mean (nt = 3 } \\
\text { to 5) }\end{array}$ & $\begin{array}{c}\text { Mean (nt }> \\
\text { 5) }\end{array}$ & \multicolumn{1}{c|}{ Sig. } \\
\hline \multicolumn{5}{|c|}{ Availability dimension } \\
\hline Cash payment & 4.442 & 4.547 & 4.298 & 0.1473 \\
\hline Credit card & 3.695 & 4.116 & 4.316 & $<1 \mathrm{e}^{-7}$ \\
\hline Debit card & 4.042 & 4.419 & 4.368 & 0.0005 \\
\hline Bank transfer & 3.358 & 3.372 & 3.509 & 0.4625 \\
\hline PayPal & 2.358 & 2.651 & 3.140 & $<1 \mathrm{e}^{-7}$ \\
\hline Traveler's check & 2.011 & 2.326 & 2.702 & $<1 \mathrm{e}^{-7}$ \\
\hline Gift cards & 2.589 & 3.000 & 3.316 & $<1 \mathrm{e}^{-7}$ \\
\hline \multicolumn{5}{|c|}{ Easiness dimension } \\
\hline Cash payment & 4.695 & 4.640 & 4.386 & 0.0167 \\
\hline Credit card & 3.747 & 4.128 & 4.404 & $<1 \mathrm{e}^{-7}$ \\
\hline Debit card & 4.221 & 4.453 & 4.667 & 0.0002 \\
\hline Bank transfer & 3.589 & 3.756 & 3.789 & 0.1948 \\
\hline PayPal & 3.042 & 3.640 & 4.054 & $<1 \mathrm{e}^{-7}$ \\
\hline Traveler's check & 2.568 & 2.930 & 3.228 & $<1 \mathrm{e}^{-7}$ \\
\hline Gift cards & 2.674 & 3.081 & 3.246 & 0.0001 \\
\hline \multicolumn{5}{|c|}{ Security dimension } \\
\hline Cash payment & 3.337 & 2.907 & 2.702 & 0.0023 \\
\hline Credit card & 3.211 & 3.628 & 3.842 & 0.0001 \\
\hline Debit card & 3.937 & 4.372 & 4.298 & $<1 \mathrm{e}^{-7}$ \\
\hline Bank transfer & 3.863 & 4.151 & 4.053 & 0.0250 \\
\hline PayPal & 3.116 & 3.430 & 3.895 & 0.0002 \\
\hline Traveler's check & 3.211 & 3.512 & 3.860 & $<1 \mathrm{e}^{-7}$ \\
\hline Gift cards & 3.432 & 3.674 & 3.982 & 0.0010 \\
\hline Auth
\end{tabular}

Source: Authors

\subsection{RQ5 - Do the benefits and disadvantages of each method of payment is perceived differently by tourists with greater value spent on their accommodations?}

The amount spent by tourists in accommodations per day has a residual impact on the perception of each payment method (Table 6). The main exception to this situation occurs for high values spent (vs) spent in accommodations (vs > $250 €$ ). In this situation, there is a statistically significant perception in the security component, in which tourists consider that the security offered by credit cards, debit cards, paypal, traveler's check, and gift cards is superior. On the contrary, this group of users considers that cash payments have worse security conditions. Lou, Tian \& Koh (2017) confirm this vision by stating that cards and mobile payments are progressively 
overcoming the use of cash. They also present other issues for the adoption of cash payments, such as lack of change, hygiene, and counterfeit currency.

It is also important to recognize that there is significant statistical evidence for users that spend least on accommodation (vs. $€ 50$ ) when using traveler's check. This group of users feels that the traveler's check has worse availability and security. However, the same conclusion cannot be made on the same group of users in the easiness component.

Table 6 Hypothesis test for the value spent by tourists on their accommodations

\begin{tabular}{|c|c|c|c|c|c|}
\hline Type of payment & $\begin{array}{c}\text { Mean }(\mathrm{vs}< \\
50 €)\end{array}$ & $\begin{array}{c}\text { Mean }(\mathrm{vs}= \\
50 € \text { to } 100 €)\end{array}$ & $\begin{array}{c}\text { Mean (vs = } \\
100 € \text { to } \\
250 €)\end{array}$ & $\begin{array}{c}\text { Mean (vs > } \\
250 €)\end{array}$ & Sig. \\
\hline \multicolumn{6}{|c|}{ Availability dimension } \\
\hline Cash payment & 4.176 & 4.625 & 4.458 & 3.667 & $<1 \mathrm{e}^{-7}$ \\
\hline Credit card & 3.618 & 3.938 & 4.177 & 4.083 & 0.0114 \\
\hline Debit card & 4.059 & 4.219 & 4.385 & 4.083 & 0.0740 \\
\hline Bank transfer & 3.235 & 3.406 & 3.396 & 3.833 & 0.1432 \\
\hline PayPal & 3.000 & 2.583 & 2.573 & 2.833 & 0.1553 \\
\hline Traveler's check & 1.794 & 2.198 & 2.479 & 2.917 & 0.0001 \\
\hline Gift cards & 2.824 & 2.865 & 2.927 & 3.417 & 0.2628 \\
\hline \multicolumn{6}{|c|}{ Easiness dimension } \\
\hline Cash payment & 4.471 & 4.771 & 4.552 & 4.000 & 0.0004 \\
\hline Credit card & 3.765 & 3.927 & 4.208 & 4.417 & 0.0188 \\
\hline Debit card & 4.324 & 4.396 & 4.438 & 4.583 & 0.6588 \\
\hline Bank transfer & 3.471 & 3.719 & 3.729 & 3.917 & 0.2323 \\
\hline PayPal & 3.735 & 3.411 & 3.458 & 3.833 & 0.3812 \\
\hline Traveler's check & 2.618 & 2.750 & 2.969 & 3.500 & 0.0071 \\
\hline Gift cards & 3.147 & 2.969 & 2.823 & 3.417 & 0.0677 \\
\hline \multicolumn{6}{|c|}{ Security dimension } \\
\hline Cash payment & 2.735 & 3.229 & 3.042 & 2.167 & 0.0088 \\
\hline Credit card & 3.411 & 3.469 & 3.479 & 4.417 & 0.0074 \\
\hline Debit card & 4.029 & 4.167 & 4.208 & 4.500 & 0.2089 \\
\hline Bank transfer & 3.765 & 4.073 & 3.990 & 4.417 & 0.0367 \\
\hline PayPal & 3.647 & 3.427 & 3.229 & 4.167 & 0.0288 \\
\hline Traveler's check & 3.029 & 3.344 & 3.667 & 4.250 & $<1 \mathrm{e}^{-7}$ \\
\hline Gift cards & 3.529 & 3.573 & 3.698 & 4.250 & 0.0713 \\
\hline
\end{tabular}

Source: Authors

\section{Conclusion}

The advantages and disadvantages of different payment methods offered by booking online platforms in tourism are perceived differently by users. Considering the seven payment methods established in this study, we can conclude that: (i) cash payment presents the greatest availability and easiness. However, it is also the one that presents the lowest security, being the perception of the security offered by this method of payment quite heterogeneous considering the profile of the users; (ii) credit card has a lower overall score in the security component, being higher in terms of availability and easiness; (iii) debit card and bank transfer have very homogeneous results in the three dimensions. However, bank transfer receives always a lower score for all dimensions when compared to the debit card; and (iv) PayPal, traveler's check and gift card receive negative ratings in the availability dimension, being the worst result obtained for travelers' check. In the easiness 
component, within these three payments, PayPal is the only one that presents a positive result. Finally, all these payment methods receive a positive evaluation in the security component.

The study also sought to assess whether users' perceptions were affected by some of their demographic, social and financial dimensions. At this level, it was possible to conclude that: (i) the tourists' gender has a residual impact on the choice of payment methods; (ii) the tourists' age is a determining factor in the choice of a payment method. This dimension is particularly relevant in the group of people 65 years and over, who prefer the use of cash payments. On the other hand, payments with credit cards, paypal, traveler's check, and gift cards are considered by this group of users as offering less availability, easiness and security; (iii) the number of trips per year performed by tourists is another factor that statistically influences the perception of payment methods, both for tourists with smaller and larger number of trips per year. Tourists with fewer trips consider that credit cards, paypal, traveler's check, and gift cards offer low levels of availability, easiness and security. This perception is precisely the opposite for the tourists who perform more than 5 trips per year; and (iv) the value spent by tourists on their accommodations is not a determining factor in the choice of payment method, except for users who spend a high amount of money in accommodations. This group considers that the security offered by credit cards, debit cards, paypal, traveler's check, and gift cards is higher.

As future work, we intend to explore the impact of mobile payments in the tourism sector, considering its adoption by both operators and tourists. At this level, we intend to assess the potential offered by these mobile payment methods (e.g., NFC, QR codes, SMS payments, mobile wallets, and WAP payments) for tourism services and we also intend to explore the main barriers and difficulties that have conditioned their market penetration.

\section{References}

1. Airbnb (2018). What methods of payment does Airbnb accept? Available at: https://www.airbnb.com/help/article/126/what-methods-of-payment-does-airbnb-accept (accessed November 2018).

2. Anderson, R. (2012). Risk and Privacy Implications of Consumer Payment Innovation. In Proceedings of the Consumer Payment Innovation in the Connected Age Conference. Kansas City, Kansas, United States.

3. Attila, A. (2016). The Impact of the Hotel Industry on the Competitiveness of Tourism Destinations in Hungary. Journal of Competitiveness, 8(4), 85-104. doi: 10.7441/joc.2016.04.06

4. Berezina, K. (2010). Top issues in PCI DSS compliance in hotels: an exploratory study. Journal of Hospitality and Tourism Technology, 1(3), 218-233. doi: 10.1108/17579881011078359

5. Bizrate (2016). Study Reveals: What Payment Options do Online Shoppers Prefer? Available at https://www.hitwise.com/blog/2016/01/what-payment-options-do-onlineshoppers-prefer/ (accessed November 2018).

6. Bogdan-Alexandru, U. (2015). Security Issues and Solutions in e-Payment Systems. Fiat Iustitia, 1, 172-179.

7. Burke-Kennedy, E. (2017). Contactless transactions drive growth in debit card use. Available at: https://www.irishtimes.com/business/financial-services/contactlesstransactions-drives-growth-in-debit-card-use-1.3294268 (accessed December 2017). 
8. Connolly, J. (2014). Gift vouchers can be irredeemably difficult to use. Available at: https://www.odt.co.nz/opinion/gift-vouchers-can-be-irredeemably-difficult-use (accessed April 2018).

9. Deshmukh, N. (2017). Online hotel reservation system trends in 2017. Available at: http://www.otrams.com/blog/online/online-hotel-reservation-system-trends-2017 (accessed December 2017).

10. Evans, J., \& Mathur, A. (2005). The value of online surveys. Internet Research, 15(2), 195219. doi: $10.1108 / 10662240510590360$

11. Filieri, R., \& McLeay, F. (2013). E-WOM and Accommodation: An Analysis of the Factors that Influence Travelers' Adoption of Information from Online Reviews. Journal of Travel Research, 53(1), 44-57. doi: 10.1177/0047287513481274

12. Finley, S. (2018). The rise of the payment app: 'I hardly use cash any more'. BBC News. Available at: https://www.bbc.com/news/business-45515666 (accessed November 2018)

13. Frenken, K., \& Schor, J. Putting the sharing economy into perspective. Environmental Innovation and Societal Transitions, 23, 3-10. doi: 10.1016/j.eist.2017.01.003

14. Goczek, E., \& Witkowski, B. (2015). Determinants of non-cash payments. Narodowy Bank Polski, NBP Working Paper, No. 196.

15. Gul, K. (2014). The effect of using credit cards on domestic and the international Turkish tourism demand in globalization. Global Business and Economics Research Journal, 3(10), 1-13.

16. Hal, S. (2015). The Importance of the Retail Payment System. In Proceedings of the Retail Payment Systems Conference. New York, United States, Harvard Law School Program on International Financial System.

17. Jiemiao, Z. (2011). Research on E-Payment Protocol. In Proceedings of Information Management, Innovation Management and Industrial Engineering (ICIII). Washington, DC, United States.

18. Ključnikov, A., Krajčík, V., Vincúrová, Z. (2018). International Sharing Economy: the Case of AirBnB in the Czech Republic. Economics and Sociology, 11(2), 126-137. doi:10.14254/2071-789X.2018/11-2/9

19. Korauš, A., Dobrovič, J., Rajnoha, R., \& Brezina, I. (2017). The safety risks related to bank cards and cyber attacks. Journal of Security and Sustainability Issues, 6(4), 563-574. doi: 10.9770/jssi.2017.6.4(3)

20. Kovács, L, \& David, S. (2016). Fraud risk in electronic payment transactions. Journal of Money Laundering Control, 19(2), 148-157. doi: 10.1108/JMLC-09-2015-0039

21. KPMG. (2017). The truth about online consumers. Available at: https://home.kpmg.com/xx/en/home/insights/2017/01/the-truth-about-onlineconsumers.html (accessed December 2017).

22. Lefever, S., Dal, M., \& Matthíasdóttir, A. (2007). Online data collection in academic research: advantages and limitations. British Journal of Educational Technology, 38(4), 574-582. doi: 10.1111/j.1467-8535.2006.00638.x

23. Lou, L., Tian, Z., \& Koh, J. (2017). Tourist Satisfaction Enhancement Using Mobile QR Code Payment: An Empirical Investigation. Sustainability, 9, 1-14. doi: 10.3390/su9071186

24. Lupu, S., Mual, M., and Stiphout, M. (2016). Ecommerce Payment Methods Report 2016. Available at: https://www.thepaypers.com/reports/ecommerce-payment-methods-report2016-global-payments-insights/r765256 (accessed December 2017). 
25. MacMillan Dictionary (2018). Available at: https://www.macmillandictionary.com

26. Mathiyazhagan, T., \& Nandan, D. 2010. Survey research method. Media Mimansa, 1(5), 34-82.

27. Niranjanamurthy, M., \& Chahar, D. (2013). The study of E-Commerce Security Issues and Solutions. International Journal of Advanced Research in Computer and Communication Engineering, 2(7), 1-12.

28. Nulty, D. (2008). The adequacy of response rates to online and paper surveys: what can be done? Assessment \& Evaluation in Higher Education, 33(3), 301-314. doi: $10.1080 / 02602930701293231$

29. Oliosi, D. (2017). Alternative payment methods used is growing on European tourism portals. Available at: http://twissen.com/tech/alternative-payment-methods-use-isgrowing-on-european-tourism-portals/ (accessed December 2017).

30. PCI (2017). PCI Security. Available at: https://www.pcisecuritystandards.org/pci_security/ (accessed December 2017).

31. Peng, R., Xiong, L., \& Yang, Z. (2012). Exploring Tourist Adoption of Tourism Mobile Payment: An Empirical Analysis. Journal of Theoretical and Applied Electronic Commerce Research, 7(1). doi: 10.4067/S0718-18762012000100003

32. Polasik, M., Górka, J., Wilczewski, G., Kunkowski, J., \& Przenajkowska, K. (2010). Time Efficiency of Point-Of-Sale Payment Methods: Preliminary Results. Journal of Internet Banking and Commerce, 15(3), 1-11.

33. Queirós, A., Faria, D., \& Almeida, F. (2017). Strengths and Limitations of Qualitative and Quantitative Research Methods. European Journal of Education Studies, 3(9), 369-387. doi: $10.5281 /$ zenodo.887089

34. Schuh, S., \& Stavins, J. (2011). How Consumers Pay: Adoption and Use of Payments. Federal Reserve Bank of Boston, 12(2), 1-35.

35. Shafer, N. (2017). Coming demise of traveler's checks. Available at: http://www.numismaticnews.net/article/coming-demise-travelers-checks (accessed April 2018).

36. Snoek, J. (2016). Payments essentials in the sharing economy. Available at: https://www.thepaypers.com/interviews/payments-essentials-in-the-sharingeconomy/767394-38 (accessed November 2018).

37. Solat, S. (2017). Security of Electronic Payment Systems: A Comprehensive Survey, arXiv:1701.04556.

38. Statista (2017). Digital travel sales worldwide from 2014 to 2020 (in billion U.S. dollars). Available at: https://www.statista.com/statistics/499694/forecast-of-online-travel-salesworldwide/ (accessed December 2017).

39. Teoh, W., Chong, S., Lin, B., \& Chua, J. (2013). Factors affecting consumers' perception of electronic payment: an empirical analysis. Internet Research, 23(4), 465-485. doi: 10.1108/IntR-09-2012-0199

40. WTTC (2017). Travel \& Tourism: Global Economic Impact \& Issues 2017. Available at: https://www.wttc.org/-/media/files/reports/economic-impact-research/2017documents/global-economic-impact-and-issues-2017.pdf (accessed December 2017).

41. Zervas, G., Proserpio, D., \& Byers, J. (2017). The Rise of the Sharing Economy: Estimating the Impact of Airbnb on the Hotel Industry. Journal of Marketing Research, 54(5), 687705. doi: 10.1509/jmr.15.0204 


\section{Brief description of Author/Authors:}

\section{Fernando Almeida}

He is a teacher and researcher at University of Porto and in the Center of Innovation, Technology and Entrepreneurship of INESC TEC, Rua Dr. Roberto Frias, s/n 4200-465 Porto, Portugal, almd@fe.up.pt

His research interests include innovation policies, entrepreneurship, tourism policies, and technology-enhanced learning.

\section{João Almeida}

He is attending a BSc. in the field of tourism management at the Higher Polytechnic Institute of Gaya, Av. dos Descobrimentos, 333 4400-103 Vila Nova de Gaia, Portugal, ispg4276@ispgaya.pt His research interests include tourism policies, and entrepreneurship and innovation in tourism.

\section{Miguel Mota}

$\mathrm{He}$ is attending a BSc. in the field of tourism management at the Higher Polytechnic Institute of Gaya, Av. dos Descobrimentos, 333 4400-103 Vila Nova de Gaia, Portugal, ispg4200@ispgaya.pt His research interests include tourism policies, events management, and tourist animation. 